University of Nebraska - Lincoln

DigitalCommons@University of Nebraska - Lincoln

Hendricks Symposium--Department of Political

Science

Political Science, Department of

October 2006

\title{
The Political Consequences of Perceived Threat and Felt Insecurity
}

Leonie Huddy

Stony Brook University

Stanley Feldman

Stony Brook University

Christopher Weber

Stony Brook University

Follow this and additional works at: https://digitalcommons.unl.edu/politicalsciencehendricks

Part of the Political Science Commons

Huddy, Leonie; Feldman, Stanley ; and Weber, Christopher, "The Political Consequences of Perceived Threat and Felt Insecurity" (2006). Hendricks Symposium--Department of Political Science. 15.

https://digitalcommons.unl.edu/politicalsciencehendricks/15

This Article is brought to you for free and open access by the Political Science, Department of at DigitalCommons@University of Nebraska - Lincoln. It has been accepted for inclusion in Hendricks Symposium-Department of Political Science by an authorized administrator of DigitalCommons@University of Nebraska - Lincoln. 


\title{
The Political Consequences of Perceived Threat and Felt Insecurity
}

\author{
Leonie Huddy, Stanley Feldman, and Christopher Weber
}

\section{Department of Political Science}

Stony Brook University

Paper presented at the Hendricks Conference on Political Behavior, Lincoln, Nebraska, October 13-14. This research was supported by Grants SES-0201650 and SES-9975063 from the National Science Foundation. We wish to thank our colleagues Charles Taber and Gallya Lahav for permission to use data from the Threat and National Security Survey. 


\begin{abstract}
We draw on data from a national RDD telephone sample of 1549 adult Americans conducted between October 15, 2001 and March 2, 2002 to explore the impact of a need for security on support for national security policies in the aftermath of the 911 terrorist attacks. In past research, an external threat has been assumed to have uniform impact on an affected population, a claim that has met with growing research scrutiny. We advance research on threat through an examination of the political effects of individual differences in one's ability to feel secure in the aftermath of terrorism, exploring the interaction between perceived threat and felt security. Most Americans reported a sense of security after the 911 attacks. But a sense of insecurity among a minority of Americans coupled with a perceived threat of future terrorism increased support for both domestic and international security policy-- the curtailment of domestic civil liberties, tougher visa checks, and support for the war in Afghanistan. Our findings underscore the diverse ways in which individuals react politically to a common external threat. We draw on attachment (Bowlby 1982/1969) and terror management theory (Pyzszcynski et al 2002) to understand the origins of individual differences in felt security.
\end{abstract}


Psychological reactions to terrorism play a pivotal role in understanding public support for government anti-terrorist policies. As Crenshaw (1986, p. 400) argues: “The political effectiveness of terrorism is importantly determined by the psychological effects of violence on audiences.” There are differing psychological reactions to external threat, however, and these reactions shape support of government policies designed to combat terrorism. In our past research we have explored the differing political implications of anxiety, anger, perceived personal threat, and perceived national threat (Huddy et al 1995; Huddy, Feldman and Cassese in print; Huddy et al 2003). In the current study, we take this research one step further to explore not only political reactions to threat but how a sense of security interacts with threat to influence support for national security policies.

Terrorists aim to threaten members of a target population directly by perpetrating random acts of violence on people engaged in everyday activities. Research on threats that involve the potential for physical harm such as crime, natural disasters, and violent conflicts provide clear evidence that personal threat increases one's sense of vulnerability and motivates action designed to minimize personal risk (Browne and Hoyt 2000; Ferraro 1996; Sattler et al 2000; Smith and Uchida 1988). We find similar evidence after 9/11. Individuals living in Queens and Long Island (in relatively close proximity to the World Trade Center) who felt personally threatened by terrorism used more caution in handling their mail, spent more time with their families, delayed or dropped their plans to travel by air, and used public transportation in Manhattan less frequently in the several months after the attacks. In this instance, perceived personal threat motivated cautionary action over and above the effects of any perceived risk of terrorism to Americans more generally (Huddy et al 2002).

Threat not only motivates protective behaviors, it also promotes support for protective government policies. Studies conducted to date find a clear relationship between national threat and support for national and domestic security policies (Davis and Silver 2004; Huddy et al 
2005). In our research on reactions to $9 / 11$, we find that perceived future terrorist threat leads to greater support for an aggressive national security policy, including increased support for the war in Afghanistan (Huddy et al 2005). Threat also heightens support for increased surveillance policies against current and potential Arab immigrants to the United States, and policies that promise increased domestic safety but threaten Americans’ civil liberties. National threat leads to support for punitive action against terrorist groups (Bar-Tal and Labin, 2001, Gordon and Arian 2001; Friedland and Merari 1985). And an adversary’s degree of belligerence and the level of threat posed to US interests increase public support for war and military action against a specific aggressor (Herrmann et al. 1999; Jentleson 1992; Jentleson and Britton 1998; Mueller 1973). Threat clearly increases support for aggressive foreign policy but it is less clear whether this serves a retaliatory function or is seen as a form of protection.

We further explore the link between threat and support of national security policy by examining the extent to which it depends on a person's sense of personal security. Some individuals are able to maintain a sense of security even in the face of threatening events that may undercut their need for protective personal and government policies (Pszczyinski et al 2002; Mikulincer and Shaver 2003; Fraley, Fazzari, Bonanno, \& Dekel, 2006.).

\section{A Need for Security: Attachment and Terror Management Theories}

There is broad agreement among social scientists that a sense of security is a basic need in humans and other species (Fraley 2005; Goldberg 2000; Mikulincer and Shaver 2003). Psychologist Abraham Maslow (1943) placed security just above the satisfaction of basic physiological needs in his hierarchy of human needs (and below love and self-actualization). And political scientist Ronald Inglehart (1997), building on Maslow’s work, viewed the fulfillment of basic economic and security needs as a necessary societal precondition to the pursuit of postmaterialist values which emphasize freedom, self-expression and quality of life. 
Bowlby's attachment theory (1982/69) is an evolutionary-developmental account of social behavior that posits a need for social proximity to protective others under conditions of threat and danger, implicitly assuming a need to maintain a sense of security under threat.

Building on Bowlby's original insights (1969) on the universality of a human need for attachment as way to deal with insecurity, scholars have theorized about the evolutionary advantage of adult attachment under conditions of threat (Ainsworth, Blehar, Water, and Well, 1978; Mikulincer and Shaver, 2003; Fraley, Brumbaugh, and Marks, 2005; Kirkpatrick, 1998; Tancredy and Fraley, 2006). Several different possibilities have been raised. First, adult attachment could improve human reproductive fitness through the process of kin selection by promoting the protection of those with whom one shares similar genes (Hamilton, 1964). Second, adult attachment could be a simple outgrowth of humans' protracted developmental period in infancy in which attachment is needed to protect offspring and stimulate complex social and cognitive skills (Bowlby, 1969; Fernald, 1993; Mikulincer and Shaver, 2003; Fraley, 2002). Third, adult attachment may foster long-lasting romantic and parenting relationships which may improve the fitness of one’s offspring (Zeifman and Hazan, 1997; although for alternative views see Belsky, 1999; Chisholm, 1996; Buss and Schmitt, 1996; Schmitt, 2005; cf., Kirkpatrick, 1998).

As noted by Sroufe and Waters (1977), the goal of attachment behaviors is to reduce anxiety through an established sense of "felt security". The attachment system emerges in early infancy, particularly in the context of the caregiver-child relationship, and operates as a functional system organizing interpersonal beliefs throughout development (Bowlby, 1969). While the attachment system is universal, operating in all humans and a host of other organisms (e.g., Fraley et al., 2005), individual differences often emerge from variations in attachment histories. Successful early attachment experiences establish one’s chronic attachment style, operating as what Bowlby (1969) referred to as an "internal working model” of the self and other 
(Bartholomew and Horowitz, 1991). Repeated episodes of successful attachment behavior give rise to a secure attachment style, which is marked by self-confidence, empathy, and trust in both children and adults (Mikulincer \& Shaver, 2003; Brennan \& Shaver, 1995; Mikulincer \& Shaver, 2001). We are primarily concerned with the difference between secure and insecure attachments in this research, but numerous researchers have investigated the consequences of differing types of insecure attachment styles.

Once established, attachment styles are relatively constant across the lifespan, suggesting that they serve as a stable individual difference (Fraley, 2002; Ainsworth, 1991) that may be mediated by distinct neural and hormonal reactions to threat. For instance, Kraemer (1992) found that physiological indicators of stress such as norepinephrine varied depending on whether rhesus monkeys were reared in isolation versus with mothers or peers. And humans with an enduring sense of insecurity release higher levels of glucocorticoids in stressful situations than those with a secure attachment (Goldberg, 2000).

A good deal of research on attachment theory has been devoted to the assessment of individual differences in attachment style, and the effects of this style on ongoing romantic relationships. But the theory is broader than that, and has been employed to understand individual differences in coping with stressful events. Typically, researchers examine the impact of attachment style on coping with various threats (for a review, see Mikulincer and Shaver 2003). Some of that research is very relevant to the study of reactions to terrorism. Mikulincer and colleagues (Mikulincer, Florian and Weller 1993) examined the effects of the Gulf War, and Iraqi Scud missile attacks, on Israelis with different attachment styles and found that securely attached individuals perceived lower levels of threat, reported higher levels of self-efficacy, actively sought out social support, and pursued constructive problem solving strategies. Former Israeli prisoners of war with a secure attachment style reported that they recalled positive 
memories or encounters with others to help cope with their imprisonment, in essence seeking symbolic proximity to internalized attachment figures (Solomon et al 1998). The need for attachment can also be activated by a mortality salience manipulation typically employed in the study of terror management theory (Mikulincer, Birnbaum, Woodis, and Nachamis 2000). Secure individuals tend to react to mortality salience with an increased desire for intimacy (Mikulincer and Florian 2000) and greater willingness to engage in social interaction (Taubman Ben-Ari, Findler, and Mikulincer 2002). In contrast, less secure individuals respond to mortality salience with more severe judgment and punishment of transgressors (Mikulincer and Florian 2000).

When taken together, research on attachment theory suggests that a long-standing sense of security derived from a secure attachment style and associated active coping strategies may help to mitigate the negative effects of stressful events. The ability to cope well with stressful events may extend to politics, undermining the need among secure individuals for government policies designed to promote a sense of safety. This possibility has not yet received empirical support but offers an intriguing explanation of how long-standing dispositions interact with events to shape support for government security policies. As a consequence, the theory may help to explain why threat is likely to drive one person to demand more powerful safety and security policies from the federal government while another is able to maintain a sense of personal security in the absence of government action.

In a popular competing view of how humans maintain a sense of ongoing security, terror management theory (Pyszczinski et al 2002) provides a related but distinct account of how individuals restore a sense of security in the face of threat, especially existential threats linked to one’s morality. Form this perspective, coping involves adherence to a cultural worldview linked, for example, to religion, moral conduct, or patriotism that boosts self-esteem and often involves the derogation of outsiders who do not share the same view. Terror management researchers 
have paid less attention to differences in the ways in which individuals restore a sense of security but recent research by Hart and colleagues (2005) suggests that differences in attachment style also moderate responses to existential threats. In their research, insecure individuals were most likely to respond to existential sthreat with more positive ratings of an ingroup member.

In this research, we closely examine whether a sense of felt security provides a buffer against threatening events and reduces the need for government action to maintain a sense of safety. We focus on both domestic and international government security policies. In essence, we test whether perceived threat coupled with a feeling of insecurity promotes support for policies that enhance domestic security but may reduce civil liberties, and leads to increased support for overseas military action.

\section{Anxiety: A Needed Control}

In turning to security as an important moderating influence on perceived threat, it is important to distinguish its effects from that of anxiety with which it is related. Our past work demonstrates that personal threat is strongly tied to a sense of heightened anxiety. Individuals who felt anxious after 9/11 experienced higher levels of personal threat and were more likely to live in New York city and have known someone who was killed or injured in the attacks (Huddy et al 2005). This highlights a key facet of anxiety. It is in part situational and affected by ongoing events as made clear by much research on state anxiety (Eysenck 1992). But this stands in marked contrast to a sense of security which, unlike anxiety, is grounded in a long-standing sense of personal safety and is unlikely to be affected by a specific stressful event. Anxiety is a product of a stressful event whereas a sense of security mitigates negative psychological reactions to such an event (Mikulincer and Shaver 2003).

Research on attachment theory makes clear that anxiety and a secure attachment style are negatively related. A secure attachment predicts better mental health under stressful circumstances, and decreased symptoms of depression and anxiety (Fraley et al, 2006). A sense 
of felt security is likely to dampen anxious reactions to the events of 9/11 and so be negatively related to it, but we expect the relationship to be modest because other situational factors such as proximity to the events or the severity of their personal impact also shape a sense of personal threat and concomitant levels of anxiety.

We also expect anxiety and security to have differing effects on domestic and national security policies. Recent psychological research demonstrates that threat-induced anxiety tends to elevate risk perceptions and risk aversion (Lerner and Keltner 2000; 2001; Lowenstein et al 2000; Raghunathan and Pham 1999). The link between anxiety and risk aversion has important implications for support of national but not domestic security policies. Anxiety is likely to elevate the perceived risks associated with a given military intervention and decrease support for the deployment of military troops, potentially undercutting a desire for retaliation. But it is unlikely to undercut support for domestic security policies which are not inherently risky. We have confirmed these predictions in our prior research on reactions to 9/11 and the Iraq war (Huddy et al 2005; Huddy, Feldman, and Cassese 2005). In contrast, both domestic and international security policies should provide a sense of security to threatened individuals who lack a strong sense of internal safety.

\section{Hypotheses}

We supplement past findings from research on terrorism with recent psychological insights from attachment and terror-management theories on the importance of felt security in dealing with stressful events. We focus specifically on the degree to which the political effects of threat depend on a sense of insecurity. We contrast the origins of felt security with other reactions to the 911 terrorist attacks, and expect security to be a more long-standing reaction than anxiety and depression that is less tied to perceived threat and the personal consequences of the attacks. Consistent with the predictions of attachment theory, we also expect felt security to moderate the influence of threat on anxiety, and produce a greater sense of trust in fellow 
Americans. We examine whether a sense of security moderates the desire to bolster self-esteem through an increase in American patriotism and denigration of outsiders, consistent with the expectations of a blended attachment-terror management approach.

Finally, we evaluate whether felt security moderates the influence of threat on support of national security policy. Felt security should decrease the influence of perceived terrorist threat on support for domestic security policies. It should also decrease the impact of threat on support for overseas military action. In contrast, insecure individuals who perceive pervasive threat should be most inclined to support both domestic and international security policy.

\section{Methods}

\section{$\underline{\text { Sample }}$}

Our data are drawn from a national telephone survey conducted with a panel of respondents at three different time points. The first wave of the national survey was conducted between early October, 2001 and early March, 2002 and includes interviews with 1,549 randomly selected adults aged 18 or older. A sample of Random Digit Dial (RDD) telephone numbers was generated by Genesys Inc. from telephone blocks with at least one listed residential number (one-plus). Respondents were selected randomly within the household using the lastbirthday method (Lavrakas 1993). The sample was drawn as a weekly rolling cross-section with roughly 100 individuals interviewed each week throughout this period. Numbers from each randomly selected sample were in use for a two-week period. The first month of data was collected by Shulman, Ronca, and Bukuvalis; the remainder of the data (including waves 2 and 3) was collected by the Stony Brook University Center for Survey Research. Up to 15 callbacks 
were made at each number and an attempt made to convert individuals who initially refused. The overall response rate was 32\% (AAPOR RR3) and the cooperation rate was 52\% (COOP3). ${ }^{1}$

The second wave of data collection occurred in October of 2002 at the end of Congressional debate on the war. Of the original interviewees, 858 were re-interviewed for a reinterview rate of 55\% roughly 7 to 12 months after the original interview. An additional 221 respondents were added to the panel from a fresh RDD sample drawn to the same specifications as the original one. This new component was designed to serve as a check on panel effects, attrition, and composition. The response rate was 39\% (RR3) and the cooperation rate was 56\% (COOP3). The third wave occurred between March and June of 2003. All three survey waves were roughly 20 minutes in length.

Our analysis focuses entirely on data from the first wave of data collection. The first wave included questions on perceptions of threat, emotional reactions and somatic symptoms linked to 9/11, support for the Bush administration, military intervention in Afghanistan, policies aimed at tightening internal security, perceptions of Arab and Arab-Americans, and patriotism, in addition to standard political and demographic items.

\section{Results}

\section{Threat and Security}

We begin by examining the perceived threat of terrorism in the aftermath of the attacks of 9/11. The survey included four items designed to measure the perceived threat of terrorism which are presented in Table 1 . Levels of national threat were quite high. Over $85 \%$ of Americans reported that they were very or somewhat concerned about another attack and 84\% were very or somewhat concerned about the threat of biological or chemical attacks. Levels of personal threat were lower, although still surprisingly high given the very small percentage of the

\footnotetext{
${ }^{1}$ There was no difference in response rate between the two survey organizations and response rates were similar to those obtained in recent RDD surveys using a different sampling frame but similar methodology (Steeh, Kirgis, Cannon, and DeWitt 2001; Losch et al. 2002).
} 
population killed in the attacks. More than two-thirds (68\%) of respondents reported being very or somewhat concerned about being personally affected by a terrorist attack; 31\% were very concerned. Over half (52\%) said that the attacks had shaken their sense of personal safety and security a great deal or some. This latter item appears to tap security, but in reality is more closely aligned with perceived personal and national threat. These four items are highly intercorrelated with a mean correlation of just under $.5(\mathrm{r}=.48)$ and a simple additive scale has an estimated reliability (coefficient alpha) of .79. The perceived threat scale ranges from 0 to 1 and has a mean of .66 and standard deviation of .24.

\section{**INSERT TABLE 1 ABOUT HERE **}

It is clear from these responses that Americans saw considerable future terrorist threat to the nation in the months after 9/11. Despite this, level of felt security were high. The majority of respondents reported feeling secure and confident when asked to "think about the terrorist attacks and the U.S. response”. About $45 \%$ of respondents said they felt secure and confident “very often," a little over a third said they felt this way "sometimes," and only 16\% said "not very often” or "never.” Thus, even when asked about their feelings in the context of the 9/11 attacks, Americans reported high levels of felt security. The two security items were highly correlated ( $\mathrm{r}=.53)$ and were combined into a scale ranging from 0 to 1 (high security) with a mean of .74.

As noted earlier, security is expected to be distinct from other emotional reactions to the attacks such as anxiety. The two security items were asked in the same battery as four anxiety questions. Respondents were again asked “As you think about the terrorist attacks and the U.S. response, how often have you felt” anxious, scared, worried, and frightened. These four responses were highly correlated (mean $r=.59$ ) and combined into a scale with an estimated reliability of .85. A confirmatory factor analysis of all six emotional reactions (anxiety and security) indicates that a two factor solution is a much better fit to the data than a single factor 
model. With the inclusion of a methods factor to account for the common response alternatives, the estimated correlation for the latent anxiety and security factors is -.35. It is thus clear that the anxiety and security measures are negatively related but are also empirically distinct.

As can be seen in Figure 1, security and anxiety also have noticeably different distributions in this sample. Consistent with previous research on secure attachments, a large fraction of the respondents score at the upper end of the security measure. Typically, roughly $75 \%$ of adults have a secure attachment style when assessed with a standard measure based on questions about romantic relationships (Hazan and Shaver 1987). The mean of the felt security scale in this study is .75 and the median is .83 , indicating that feeling secure is the modal response among respondents. While the mass of the data are close to the high end of the scale there is a definite lower tail to the distribution that extends to the low end of the scale (3.5\% of the respondents obtained a value of 0 ). In contrast, anxiety is distributed in a less concentrated fashion with a mean of .39 and a median of .33. High scores on anxiety are much more common in these data than low scores on security as can be seen in Figure 1.

**INSERT FIGURE 1 ABOUT HERE **

\section{Determinants of Anxiety, Depression, and Security}

The nature of security can be seen more clearly when we examine its predictors along with the determinants of anxiety and reported symptoms of depression. To measure feelings of depression, respondents were asked "In the past week, how depressed have you felt, if at all, about the terrorist attacks and the events since then?” with response options ranging from very to not at all. Similar questions were asked about how much difficulty they had concentrating on their job, and trouble sleeping. Responses to these questions had a mean inter-item correlation of .58 and were combined into an additive scale ranging from 0 to 1 . We estimated two models to assess the respective determinants of anxiety, feelings of depression, and felt security. The first model includes demographic variables (age, education, gender, race/ethnicity), political variables 
(partisan and ideological identification and authoritarianism), and physical and emotional proximity to the 9/11 attacks (living in the Northeast and knowing someone hurt or killed in the attacks). Perceived threat was added to these equations in a second set of models. Estimates of these regression equations are shown in Table 2.

\section{**INSERT TABLE 2 ABOUT HERE **}

At the outset, we expected anxiety and depression to be closely linked to different aspects of the terrorist attacks, but did not hold the same expectations of felt security because of its theoretical status as a more enduring and stable individual difference. This expectation is largely supported in Table 2. Physical proximity to the September 11 attacks, as indicated by living in the Northeast of the U.S., had a significant effect on both anxiety and depression. Knowing someone who was killed in the attacks also increased levels of both variables. ${ }^{2}$ In contrast, physical and emotional proximity to the attacks did not decrease feelings of personal security. Indeed, there were few other significant predictors of security. Most notably, women reported feeing less secure than men, older people felt more secure than younger respondents, and blacks felt slightly less secure than whites. Political beliefs and allegiances also influenced anxiety and depression. Republicans felt less anxious and depressed, and authoritarians felt more so. But once again the determinants of felt security differ which was unrelated to partisanship, political ideology, or authoritarianism.

The relative stability of feelings of security is also suggested by the results of a second set of estimates obtained by adding perceived threat to each of the basic models in Table 2. As seen in this table, threat has large effects on anxiety and symptoms of depression. Anxiety in particular rises rapidly with increases in perceived threat. While the effect of threat is significant in the security equation, it is small compared to its coefficients in the other two equations. The effect of

\footnotetext{
2 The exact question wording is "Do you, any of your friends, or relatives know someone who is missing, hurt, or killed in the terrorist attacks of September 11?
} 
threat on security is less that a fourth the size of its effect on anxiety (coefficients can be simply compared because each variable is measured on a 0-1 scale). Thus while anxiety and depression were strongly related to the threat of terrorism, those same threat perceptions only slightly dampened feelings of security.

In general, there is much less variation in security across social and political variables than is seen for anxiety or depression and it has no obvious relationship to variables that convey the impact of physical or social proximity to the attacks and its victims. Overall, threat and demographic factors accounted for $6 \%$ of the variance in felt security compared to $26 \%$ of the variance in depressions and an impressive $42 \%$ of variance in anxiety. When taken together, these findings provide indirect evidence that feelings of security may be a long standing reaction that is relatively unaffected by ongoing events or standard political attitudes and beliefs, although we do not have conclusive evidence on this point. $\underline{\text { Interpersonal and Emotional Consequences of Security }}$

According to attachment theory, one of the key correlates of a secure attachment is a general willingness to trust other people. In order to determine whether our simple measure of felt psychological security produces higher levels of trust in other people we estimated two probit models for questions in our survey that involve trust in other Americans. ${ }^{3}$ The estimates of these equations are shown in Table 3. In both cases an increased sense of security is related to a trust in Americans and a view of them as helpful. In both equations the estimates imply that as security varies from low to high the probability of trusting other people increases by about .2 (all other predictors held constant at their mean) or a fifth of the scale range. Trust in people also increases somewhat with increasing age and education; blacks are less trusting of other Americans and

\footnotetext{
${ }^{3}$ The two questions are: Generally speaking, would you say that most Americans can be trusted, or do you believe that you can't be too careful in dealing with other people? And Would you say that most of the time Americans try to be helpful, or that they are just looking out for themselves?
} 
view them as less helpful than do whites. Finally, women, Hispanics, and authoritarians are less trusting of other Americans than men, Anglos, and non-authoritarians respectively.

**INSERT TABLE 3 ABOUT HERE **

According to attachment theory, one of the key functions of a secure attachment is to promote active coping that helps to deal with stress and mitigate its negative psychological consequences. Thus, among people who perceive themselves to be personally at threat from terrorism, feeling secure should result in lower levels of psychological distress than among the insecure. To test the buffering hypothesis, we estimated a regression model for anxiety and depression that included perceived threat, security, and their interaction along with other standard demographic predictors. As shown in Table 4 there is a sizable coefficient for both threat and its interaction with security. With threat and security both ranging from 0 to 1 , the coefficient for security indicates its effect when security is at its minimum. The impact is clearly large. Among the least secure, perceived threat produces considerable anxiety and depression. There is also a significant interaction between threat and security. The impact of threat among the most secure can be calculated by adding the coefficient for threat to that of the interaction. This indicates that the psychological impact of threat is reduced substantially among the most secure. In fact, it is almost halved for depression. These findings lend support to the notion that security minimized the psychological impact of the 911 terrorist attacks.

**INSERT TABLE 4 ABOUT HERE **

According to a blended terror-management attachment theory approach, threat should produce heightened ingroup attachments and increased outgroup derogation among insecure individuals as another way in which to restore their sense of security (Hart et al 2005). We examine the extent to which threat, security, and their interaction influence levels of symbolic patriotism and negative stereotyping of Arabs in regression equations presented in Table 5. In this analysis, symbolic patriotism is a scale made up of two items: pride in being American and 
good feelings in response to the flag ( $\mathrm{r}=.61)$. Arab stereotyping is assessed with four items asking how well the words trustworthy, honest, violent and extremist described most Arabs (mean $\mathrm{r}=.36$, alpha=. 7).

As seen in Table 5, the coefficient for threat and its interaction with security are statistically significant for symbolic patriotism. The coefficient for threat indicates the impact of threat when felt security is at zero. And the impact on patriotism is clearly sizeable. Threat produces a substantial increase in symbolic patriotism among insecure individuals but has a much more modest positive effect on patriotism among the most secure. Threat also enhances negative Arab stereotypes but its interaction with security is not significant. The absence of a significant interaction between threat and security means that perceived threat promotes negative stereotypes of Arabs regardless of felt security. Overall, it appears that insecure individuals respond to the threat of terrorism with enhanced ingroup attachment as reflected in higher levels of reported patriotism. But outgroup derogation is driven simply by threat. These findings highlight the importance of patriotism and ingroup attachments as a way to restore a sense of security in the face of threat. In contrast, outgroup derogation may simply reflect the vilification of a threatening outgroup that has little to do with a sense of personal security. Overall, these findings are partially consistent with the predictions of a combined version of attachment and terror management theory.

**INSERT TABLE 5 ABOUT HERE **

\section{Domestic Security Policies}

We now turn to an examination of the effects of threat on support for domestic security policies. The survey included two specific proposals to limit general civil liberties in order to reduce the threat of terror: requiring national identity cards and allowing the government to monitor personal phone calls and emails of ordinary Americans. We also asked respondents if 
they were more concerned that the country would fail to enact strong anti-terrorism laws or if they were more worried that new laws would restrict civil liberties.

Three additional questions focused on activities designed to monitor and restrict the activities of people who might be considered threatening. Question included whether Arabs and Arab-Americans in the U.S. should be put under special surveillance, support for greater restrictions on visas for foreign students and other visitors to the U.S., and whether Arabs should undergo more intensive security checks than visitors from other countries. Probit estimates for the first three domestic security measures are shown in Table 5 and estimates for the second set of security restrictions are presented in Table 6. In all equations we include as predictors national threat, security, and the interaction between threat and security, along with demographic controls.

The results in Table 5 show that increasing perceptions of threat predict greater support for both domestic security measures and lesser concern with civil liberties. With the inclusion of an interaction term between threat and security, the coefficient for perceived threat yields its effect when security is 0 . In all three equations there are large, significant effects of threat when security is low, indicating that perceived threat has a sizeable influence on policy support among the least secure. In two of the three equations the interaction term is also substantively large, significant at the .05 level with a one-tailed test, and in the predicted direction. The significant interaction terms indicate that threat is less likely to promote support for a national identity card and is less likely to increase concerns about a failure to enact strong anti-terrorism laws among the most secure. In both instances, the effect of threat on support for domestic security policies decreases as security increases. The size of the interaction term indicates that the effect of threat, while smaller for those high in security, does not fully decline to 0 . There is no interaction between security and threat for monitoring phones and emails, however. The estimates for that equation indicate that the effect of threat is not reduced by felt security. 
**INSERT TABLE 6 ABOUT HERE **

Among the other independent variables, the most consistent predictors of support for internal security measures are political orientations: conservatives and Republicans are more likely to support these policies than liberals and Democrats, and authoritarianism is associated with greater support. In addition, support for these policies decreases somewhat as education increases.

The three policies just examined involve security measures that would directly impact most Americans. The second set of policies assess support for more targeted "threats" to security by focusing on Arabs and other foreign visitors to the U.S. The estimates for these equations, shown in Table 7, are broadly similar to those just discussed, with some significant differences. Notice first that, for all three equations, the interaction between personal threat and security is in the predicted direction, significant at the .05 level in a one-tailed test, and substantively large. As before, when security is at its lowest value, the effect of personal threat on support for security policies is large. In two of these cases, surveillance and stricter security checks, the interaction between personal threat and felt security is sufficiently large that personal threat has no impact among those who feel completely secure. Thus, security reduces the effects of threat on support for these targeted policies than for more general domestic surveillance policies.

**INSERT TABLE 7 ABOUT HERE **

As an illustration of the magnitude of threat effects we present predicted probabilities at differing levels of threat and security for two of the domestic security policies - the national ID card and special surveillance for Arabs and Arab-Americans. Predicted probabilities are calculated for white males who score at the midpoint on all other independent variables in Tables 6 and 7. Among those scoring at the lowest value of felt security, under $20 \%$ are predicted to support national ID cards at the lowest level of perceived threat; this goes up to almost $80 \%$ among those who see maximum threat. This is a massive difference. The effects of threat are 
more muted among those high in security, ranging from a predicted low of $38 \%$ when threat is low to a $64 \%$ when it is high. A similar trend is observed on support for increased surveillance of Arabs and Arab Americans. Among those low in security, predicted support for increased surveillance goes from a low of $9 \%$ to a high of $58 \%$ as threat ranges from its lowest to highest value. Among those high in security, predicted support for surveillance varies less dramatically with level of threat ranging from $26 \%$ to $37 \%$. It is also clear that there those with a high sense of felt security who see little terrorist threat are more supportive of security policies than their less secure counterparts, a somewhat puzzling finding that requires further investigation.

\section{Threat and Support for Military Action}

We also examined the impact of threat and security on support for overseas military action in response to the events of 9/11. Three questions tapped support for the military intervention in Afghanistan and more generally asking whether "the level of US military action in response to the terrorist attacks” was sufficient, whether the strength of support for “increasing the level of military action even if it means that U.S. armed forces might suffer a substantial number of casualties", and whether "the US should limit its military action to Osama bin Laden and the Taliban or should it broaden its action to include other countries that harbor and support terrorists.” Ordered probit analyses were conducted to assess the determinants of support for each one of these questions; findings are reported in Table 8.

Previous analyses of these data provide evidence that threat has a substantial, positive impact on support for overseas military action (Huddy et al 2005). This finding is confirmed in the current analysis but is further qualified by evidence of a sizeable interaction between threat and security. As seen in Table 8, threat has substantial impact on all three indicators of support for military action when security is at its lowest level, as indicated by the coefficient for threat in Table 7. In addition, the interaction between threat and security is sizeable and significant for level of military action and a desire to expand action beyond Osama bin Laden and the Taliban. 
In both instances, the effects of threat on support for military action are greatly reduced among the most secure. There is also a sizeable but non-significant interaction between threat and security that almost halves the impact of threat on support for increased military action even with casualties among the most secure.

As for domestic policy, felt security has a sizeable moderating influence on the degree to which threat increases support for national security policy. Based on the analyses presented in Table 8, we calculated the predicted probability that respondents rated the U.S. level of military action in response to 911 as “too little”. Among those who felt insecure, roughly 6\% who perceived little threat thought the response had been inadequate compared to $54 \%$ of those who perceived maximum future threat to the U.S. In contrast threat had a much reduced effect on policy support among those who felt the most secure. Fifteen percent of the most secure who perceived little terrorist threat thought the U.S. response had been inadequate compared to $27 \%$ of those who perceived the U.S. as facing the highest level of threat, a far more muted difference. Felt security clearly moderates the influence of threat on American support for overseas military action.

\section{**INSERT TABLE 8 ABOUT HERE **}

Finally, a number of other factors influenced support for an aggressive foreign policy. Men, non-blacks, Republicans, conservatives, and authoritarians were generally more supportive of overseas military intervention than others, as seen in Table 8.

\section{Conclusion}

Not everyone responds to the threat of terrorism in the same way. In this study, we have highlighted the powerful moderating influence of felt security on the extent to which perceived threat leads to support for restrictive domestic security policy and aggressive international action. We have shown in past research that feelings of national threat promote support for an 
aggressive foreign policy (Huddy et al 2005). The current findings temper that conclusion by demonstrating that the greatest impact of threat is concentrated among individuals who had difficulty maintaining a sense of security in the months following the terrorist attacks of 911 . We also highlight the powerful influence of security and threat on support for domestic national security policies that potentially curtail American civil liberties. For both domestic and international security policy, feeling insecure can profoundly influence whether or not individuals seek a sense of personal security in government policy.

Our research not only sheds light on reactions to the events of 9/11, but also provides an important extension to existing research on tolerance and civil liberties by demonstrating the powerful and distinct effects of threat. Past tolerance studies have typically found a strong desire to curtail the rights and liberties of members of groups that pose a broad societal threat (Marcus et al 1995; Sullivan et al. 1982). But researchers have paid much less attention to the willingness of study participants to forego their own liberties and freedoms. Findings from the current study suggest that this depends centrally on the combined experience of threat and insecurity. In our data, a sense of personal insecurity plays a central role in a willingness to forfeit personal liberties in response to an external threat, suggesting new avenues for research on political tolerance.

Drawing on psychological attachment theory, we suggest that feelings of security are a long standing individual characteristic that may derive from early childhood attachment experiences. Attachment theory indicates that most adults achieve a secure attachment and this, in turn, improves their ability to deal with stress through imagined or real proximity to attachment figures. But more is needed to establish the links between felt security as measured in a survey context and more standard measures of attachment, in order to verify that felt security has many of the same properties. We uncover suggestive evidence consistent with attachment theory that felt security was not greatly affected by the terrorist attacks of 911, and was much less affected 
than other reactions such as anxiety or depression. Felt security helped to minimize feelings of anxiety, promoted a sense of trust in other Americans, and mitigated the need to elevate feelings of symbolic patriotism as a way to cope with threat. When taken together, these findings suggest that felt security plays a central role in how people cope with stressful events and whether or not such events are translated into a desire for protective government policies.

But more information is needed on a sense of felt security to ensure that it fully conforms to the expectations of attachment theory. How well does a sense of felt security correlate with other more standard measures of attachment style within romantic relationships? What evidence is there that a sense of felt security is stable over time, and relatively immune to the impact of ongoing events? And is there evidence that the impact of felt security can be observed in response to other government policies designed to handle frightening events such as avian flu or food contamination? Further research into felt security will help to determine the kinds of individuals most likely to support aggressive government action to deal with threatening events. 


\section{References}

Ainsworth, M. D. S. (1991). Attachments and other affectional bonds across the life cycle. In C. M. Parkes, J. Stevenson-Hinde \& P. Marris (Eds.), Attachment across the life cycle. (pp. 33-51): Tavistock/Routledge.

Ainsworth, M. D. S., Blehar, M. C., Waters, E., \& Walls, S. (1978). Patterns of Attachment: Assessed in the strange situation and at home. Hillsdale, NJ: Erlbaum.

Arien, A., \& Gordon, C. (1993). The political and psychological impact of the Gulf War on the Israeli public. Pittsburgh: University of Pittsburgh Press.

Bar-Tal, D., \& Labin, D. (2001). The effect of a major event on stereotyping: Terrorist attacks in Israel and Israeli adolescents’ perceptions of Palestinians, Jordanians and Arabs. European Journal of Social Psychology, 31, 265-280.

Bartholomew, K., \& Horowitz, L. M. (1991). Attachment styles among young adults: A test of a four-category model. Journal of Personality and Social Psychology, 61, 226-244.

Bartholomew, K., \& Shaver, P. R. (1998). Methods of assessing adult attachment: Do they converge? In J. A. Simpson \& W. S. Rholes (Eds.), Attachment theory and close relationships. (pp. 25-45): Guilford Press.

Begley, T. M., \& Alker, H. (1982). Anti-Busing protest: Attitudes and actions. Social Psychology Quarterly, 45, 187-197.

Belsky, J. (1999). Modern evolutionary theory and patterns of attachment. In J. Cassidy \& P. R. Shaver (Eds.), Handbook of attachment: Theory, research, and clinical applications. (pp. 141-161): Guilford Press.

Bowlby, J. (1969). Attachment and loss. New York: Basic Books. 
Brennan, K. A., \& Shaver, P. R. (1995). Dimensions of adult attachment, affect regulation, and romantic relationship functioning. Personality and Social Psychology Bulletin, 21, 267283.

Brennan, K. A., Clark, C. L., \& Shaver, P. R. (1998). Self-report measurement of adult attachment: An integrative overview. In J. A. Simpson \& W. S. Rholes (Eds.), Attachment theory and close relationships. (pp. 46-76): Guilford Press.

Browne, M.J., and Hoyt, R.E. (2000). The demand for flood insurance: Empirical evidence. Journal of Risk and Uncertainty, 20, 271-289.

Buss, D. M., \& Schmitt, D. P. (1993). Sexual Strategies Theory: An evolutionary perspective on human mating. Psychological Review, 100, 204-232.

Chisholm, J. S. (1996). The evolutionary ecology of attachment organization. Human Nature, 7(1), 1-38.

Citrin, J., Green, D. P., \& Muste, C. (1997). Public opinion toward immigration reform: The role of economic motivations. The Journal of Politics, 59, 858-881.

Crenshaw, Martha. 1986. The Psychology of Political Terrorism. In Political Psychology, ed. Margaret G. Hermann. New York: Jossey-Bass, pp.

Davis, D. W., \& Silver, B. D. (2004). Civil liberties versus security in the context of the terrorist attacks on America. American Journal of Political Science, 48, 28-46.

Eysenck, M. W. (1992). Anxiety: The Cognitive Perspective. London: Lawrence Erlbaum Associates Ltd.

Feldman, S. (1988). Economic self-interest and political behavior. American Journal of Political Science 26, 446-466.

Fernald, A. (1992). Human maternal vocalizations to infants as biologically relevant signals: An evolutionary perspective. In J. H. Barkow, L. Cosmides \& J. Tooby (Eds.), The adapted 
mind: Evolutionary psychology and the generation of culture. (pp. 391-428): Oxford University Press.

Ferraro, K. A. (1996). Women's fear of victimization: shadow of sexual assault? Social Forces, 75, 667-690.

Fraley, R. C. (2002). Attachment stability from infancy to adulthood: Meta-analysis and dynamic modeling of developmental mechanisms. Personality and Social Psychology Review, 6(2), 123-151.

Fraley, R. C., Brumbaugh, C. C., \& Marks, M. J. (2005). The Evolution and Function of Adult Attachment: A Comparative and Phylogenetic Analysis. Journal of Personality and Social Psychology, 89, 731-746.

Fraley, R. C., Fazzari, D. A., Bonanno, G. A., \& Dekel, S. (2006). Attachment and Psychological Adaptation in High Exposure Survivors of the September 11th Attack on the World Trade Center. Personality and Social Psychology Bulletin, 32(4), 538-551.

Friedland, N., \& and Merari, A. (1985). The psychological impact of terrorism: A double-edged sword.” Political Psychology, 6, 591-604.

Gibson, J. L. (1998). A Sober Second Thought: An Experiment in persuading Russians to tolerate. American Journal of Political Science, 42, 819-850.

Gibson, J. L. (2005). Enigmas of tolerance: Fifty years after Stouffer's communism, conformity, and civil liberties. Washington University.

Goldberg, S. (2000). Attachment and development. London: Oxford University Press.

Gordon, C., \& Asher, A. (2001). Threat and decision making. Journal of Conflict Resolution, 45, $197-215$

Green, D. P., \& Cowden, J.A. (1992). Who protests: Self-interest and white opposition to busing. Journal of Politics, 54, 471-496. 
Hamilton, W. D. (1964). The genetic evolution of social behaviour. Journal of Theoretical Biology, 7, 1-52.

Herrmann, Richard K., Philip E. Tetlock, and Penny S. Visser. 1999. "Mass Public Decisions to Go to War: A Cognitive-Interactionist Framework.” American Political Science Review, 93(3): 553-573.

Huddy, L. (2003). Group Membership, Ingroup Loyalty, and Political Cohesion. In D. O. Sears, L. Huddy \& R. Jervis (Eds.), Handbook of Political Psychology (pp. 511-558). New York Oxford University Press.

Huddy, L., Feldman, S., Capelos, T., \& Provost, C. (2002). The consequences of terrorism: Disentangling the effects of personal and national threat. Political Psychology, 23, 485509.

Huddy, L., Feldman, S., \& Cassese, E. (2005). On the distinct political effects of anxiety and anger.

Huddy, L., Feldman, S., Taber, C., \& Lahav, G. (2005). Threat, Anxiety, and Support of AntiTerrorism Policies American Journal of Political Science, 49, 610-625.

Jentleson, B. (1992). The Pretty Prudent Public: Post post-Vietnam American opinion on the use of force. International Studies Quarterly, 36, 49-74

Jentleson, B. W., \& Britton., R. L. (1998). Still Pretty Prudent: Post-Cold War American public opinion on the use of military force. Journal of Conflict Resolution, 42, 395-417.

Kinder, D. R., \& Kiewiet, D. R. (1981). Sociotropic politics: the American case. British Journal of Political Science, 11, 129-162.

Kinder, D. R., \& Sears, D. O. . (1985). Public opinion and political action. In G. Lindzey \& E. Aronson (Eds.), Handbook of social psychology (pp. 659-741). New York: Random House. 
Kinder, D.R., \& Sears, D.O. (1981). Prejudice and politics: Symbolic racism versus racial threats to the good life. Journal of Personality and Social Psychology, 40, 414-431.

Kirkpatrick, L. A. (1998). Evolution, pair-bonding, and reproductive strategies: A reconceptualization of adult attachment. In J. A. Simpson \& W. S. Rholes (Eds.), Attachment theory and close relationships. (pp. 353-393): Guilford Press.

Kraemer, G. W. (1992). A psychobiological theory of attachment. Behavioral and Brain Sciences, 15(3), 493-541.

Lavine, H., Lodge, M., Polichak, J., \& Taber, C. (2002). Explicating the black box through experimentation: Studies of authoritarianism and threat. Political Analysis, 10, 342-360.

Lavrakas, P. J. (1993). Telephone survey methods: Sampling, selection and supervision. Newbury Park, CA: Sage.

Lerner, J. S., \& Keltner, D. (2000). Beyond valence: Toward a model of emotion-specific influences on judgment and choice. Cognition and Emotion 14(4), 473-493.

Lerner, J. S., \& Keltner, D. (2001). Fear, anger, and risk. Journal of Personality and Social Psychology 81, 146-159.

Losch, M. E., Maitland, A., Lutz, G., Mariolis, P., \& Gleason, S. (2002). The effect of time of year of data collection on sample efficiency. Public Opinion Quarterly, 66 594-607.

Lowenstein, G. F., Weber, E. U., Haste, C. K., \& Welch, N. (2001). Risk as Feelings. Psychological Bulletin, 127 267-286.

Marcus, G. E., Sullivan, J. L., Theiss-Morse, E., \& Wood, S. L. (1995). With malice toward some: How people make civil liberties judgments. Cambridge, MA Cambridge University Press.

Maslow, Abraham H. 1943. A Theory of Human Motivation. Psychological Review, 50 (4): 37096. 
Mikulincer, M., Birnbaum, G., Woddis, D., \& Nachmias, O. (2000). Stress and accessibility of proximity-related thoughts: Exploring the normative and intraindividual components of attachment theory. Journal of Personality and Social Psychology, 78(3), 509-523.

Mikulincer, M., Florian, V., \& Weller, A. (1993). Attachment styles, coping strategies, and posttraumatic psychological distress: The impact of the Gulf War in Israel. Journal of Personality and Social Psychology, 64(5), 817-826.

Mikulincer, M., Gillath, O., \& Shaver, P. R. (2002). Activation of the attachment system in adulthood: Threat-related primes increase the accessibility of mental representations of attachment figures. Journal of Personality and Social Psychology, 83(4), 881-895.

Mikulincer, M., \& Shaver, P. R. (2003). The attachment behavioral system in adulthood: Activation, psychodynamics, and interpersonal processes. In M. P. Zanna (Ed.), Advances in experimental social psychology, Vol. 35. (pp. 53-152): Elsevier Academic Press.

Mueller, J. E. (1973). War, presidents, and public opinion. New York: John Wiley. Pyszczynski, T., Solomon, S., \& Greenberg, J. (2002). In the wake of 9/11: The Psychology of Terror. Washington, D.C.: APA.

Raghunathan, R., \& Pham, M. T. (1999). All negative moods are not equal: Motivational influences of anxiety and sadness on decision making. Organizational Behavior and Human Decision Processes 79, 56-77.

Sattler, D. N., Kaiser, C. F., \& Hittner, J. B. (2000). Disaster preparedness: Relationships among prior experience, personal characteristics, and distress. Journal of Applied Social Psychology, 37, 1396-1420.

Schmitt, D. P. (2005). Is Short-Term Mating the Maladaptive Result of Insecure Attachment? A Test of Competing Evolutionary Perspectives. Personality and Social Psychology Bulletin, 31(6), 747-768. 
Sears, D. O., \& Funk, C. (1991). The role of self-interest in social and political attitudes. Advances in Experimental Psychology, 24, 1-91.

Sears, D. O., Lau, R. R., Tyler, T. R., \& Allen Jr., H. M. (1980). Self-interest vs. symbolic politics in policy attitudes and presidential voting. American Political Science Review, 74, 670-84.

Smith, T. W., \& Rasinski, K. A. (2002). Assassination and terror: Two American tragedies compared Public Perspective, (September/October), 34-38.

Smith, D. A. \& Uchida, C. D. (1988). The social organization of self-help: a study of defensive weapon ownership. American Sociological Review, 53, 94-102.

Solomon, Z., Ginzburg, K., Mikulincer, M., Neria, Y., \& Ohry, A. (1998). Coping with war captivity: The role of attachment style. European Journal of Personality, 12, 271-285.

Steeh, C., Kirgis, N., Cannon, B., \& Jeff DeWitt, J. (2001). Are they really as bad as they seem? Nonresponse rates at the end of the twentieth century. Journal of Official Statistics, 17, 227-247.

Sullivan., J. L., Piereson, J., \& Marcus, G. E. (1982). Political Tolerance and American Democracy. Chicago: University of Chicago Press

Tancredy, C. M., \& Fraley, R. C. (2006). The Nature of Adult Twin Relationships : An Attachment-Theoretical Perspective. Journal of Personality and Social Psychology, 90(1), 78-93.

Taubman Ben-Ari, O., Findler, L., \& Mikulincer, M. (2002). The effects of mortality salience on relationship strivings and beliefs: The moderating role of attachment style. British Journal of Social Psychology, 41, 419-441.

Zeifman, D., \& Hazan, C. (1997). Attachment: The bond in pair-bonds. In J. A. Simpson \& D. T. Kenrick (Eds.), Evolutionary social psychology. (pp. 237-263): Lawrence Erlbaum Associates, Inc. 


\section{Table 1}

\section{Frequency Distributions of Threat and Security Items}

\section{Threat:}

How concerned are you that there will be another terrorist attack on U.S. soil in the near future?

How concerned are you that terrorists will attack the U.S. with biological or chemical weapons?

How concerned are you personally about you yourself, a friend, or a relative being the victim of a future terrorist attack in the United States?

How much, if any, have the terrorist attacks shaken your own sense of personal safety and security?

\section{Security:}

As you think about the terrorist attacks and the U.S. response, how often have you felt...

$$
\begin{aligned}
& \text { Secure? } \\
& \text { Confident? }
\end{aligned}
$$

$\begin{array}{cccc}\text { Very } & \text { Somewhat } & \text { Not Very } & \text { Not At All } \\ \text { Concerned } & \text { Concerned } & \text { Concerned } & \text { Concerned }\end{array}$

DK/NA

$49.8 \%$

36.5

9.7

3.5

0.4

$47.3 \%$

37.4

10.2

3.8

1.3

$30.8 \%$

37.1

19.8

11.2

1.2

A Great

Deal

Some

A Little

Not At All

DK/NA

$17.8 \%$

34.2

23.4

23.8

0.9

$\begin{array}{ccccc}\begin{array}{c}\text { Very } \\ \text { Often }\end{array} & \text { Sometimes } & \begin{array}{c}\text { Not Very } \\ \text { Often }\end{array} & \text { Never } & \text { DK/NA } \\ 45.0 \% & 36.2 & 10.8 & 6.4 & 1.7 \\ 46.4 \% & 35.6 & 9.5 & 5.6 & 2.9\end{array}$


Figure 1

Kernel Density Plots for Anxiety and Security

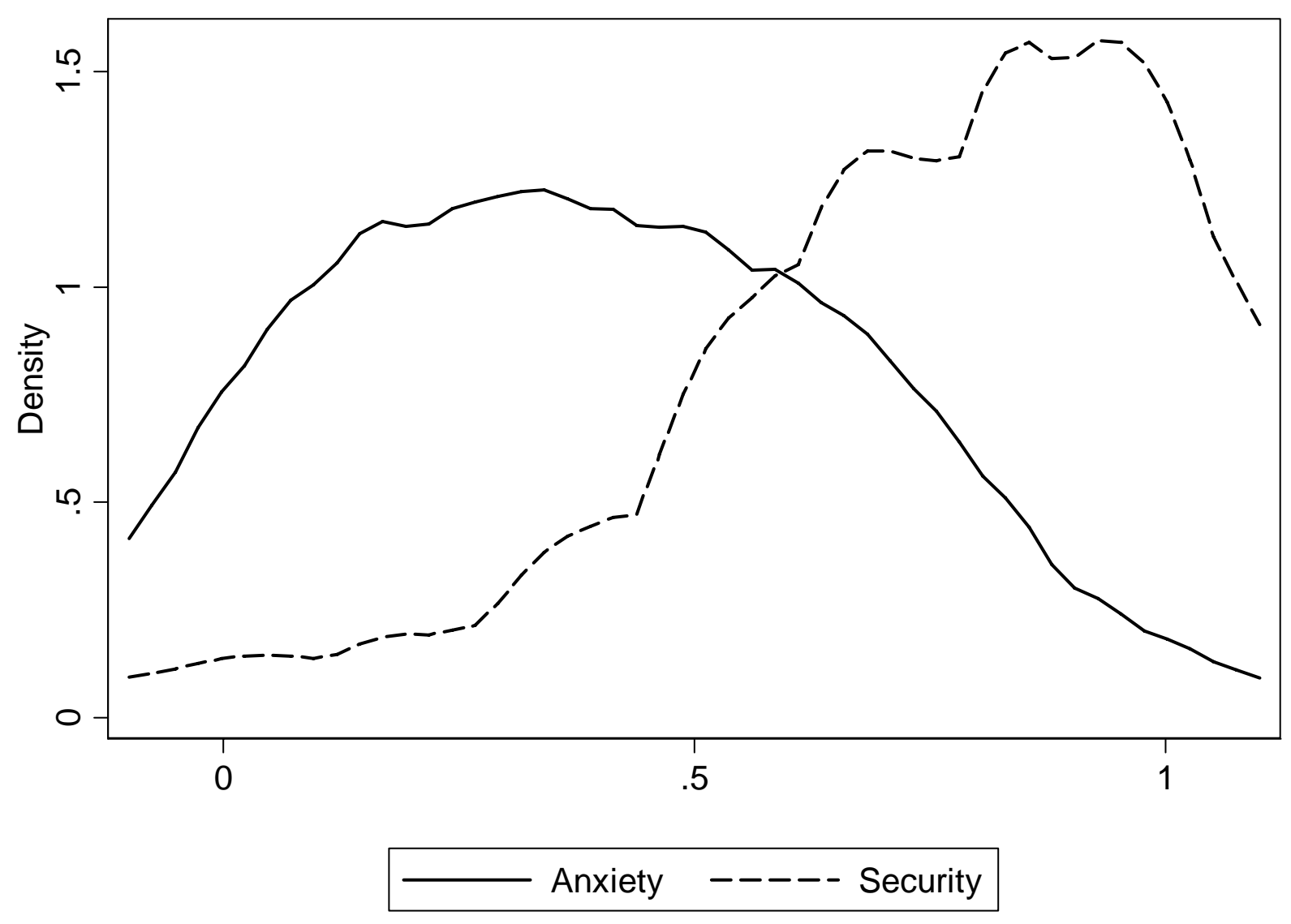


Table 2

Determinants of Anxiety, Depression, and Security

\begin{tabular}{|c|c|c|c|c|c|c|}
\hline \multirow[b]{2}{*}{ Know Someone Killed } & \multicolumn{2}{|c|}{ Anxiety } & \multicolumn{2}{|c|}{ Depression } & \multicolumn{2}{|c|}{ Security } \\
\hline & .07 & .04 & .06 & .04 & -.01 & .00 \\
\hline Live in Northeast & $\begin{array}{l}(.02) \\
.05\end{array}$ & $\begin{array}{c}(.01) \\
.01\end{array}$ & $\begin{array}{c}(.01) \\
.06\end{array}$ & $\begin{array}{c}(.01) \\
.03\end{array}$ & $\begin{array}{l}(.02) \\
-.02\end{array}$ & $\begin{array}{l}(.02) \\
-.01\end{array}$ \\
\hline Threat & $(.02)$ & $\begin{array}{c}(.02) \\
.61\end{array}$ & $(.02)$ & $\begin{array}{c}(.02) \\
.45\end{array}$ & $(.02)$ & $\begin{array}{l}(.02) \\
-. .14\end{array}$ \\
\hline Age & -.013 & $\begin{array}{l}(.02) \\
-.014\end{array}$ & .006 & $\begin{array}{c}(.02) \\
.006\end{array}$ & .008 & $\begin{array}{c}(.03) \\
.008\end{array}$ \\
\hline Education & $\begin{array}{l}(.004) \\
-.014\end{array}$ & $\begin{array}{l}(.003) \\
-.006\end{array}$ & $\begin{array}{l}(.004) \\
-.016\end{array}$ & $\begin{array}{l}(.004) \\
-.011\end{array}$ & $\begin{array}{c}(.004) \\
.002\end{array}$ & $\begin{array}{c}(.004) \\
.000\end{array}$ \\
\hline Gender (female) & $\begin{array}{l}(.003) \\
.18\end{array}$ & $\begin{array}{l}(.002) \\
.12\end{array}$ & $\begin{array}{c}(.003) \\
.06\end{array}$ & $\begin{array}{c}(.002) \\
.02\end{array}$ & $\begin{array}{l}(.003) \\
-.09\end{array}$ & $\begin{array}{l}(.003) \\
-.07\end{array}$ \\
\hline Black & $\begin{array}{l}(.01) \\
-.00\end{array}$ & $\begin{array}{l}(.01) \\
-.05\end{array}$ & $\begin{array}{c}(.01) \\
.08\end{array}$ & $\begin{array}{c}(.01) \\
.05\end{array}$ & $\begin{array}{l}(.01) \\
-.06\end{array}$ & $\begin{array}{l}(.01) \\
-.05\end{array}$ \\
\hline Hispanic & $\begin{array}{c}(.03) \\
.04\end{array}$ & $\begin{array}{c}(.02) \\
.00\end{array}$ & $\begin{array}{c}(.02) \\
.11\end{array}$ & $\begin{array}{c}(.02) \\
.08\end{array}$ & $\begin{array}{c}(.03) \\
.02\end{array}$ & $\begin{array}{c}(.03) \\
.01\end{array}$ \\
\hline Other & $\begin{array}{c}(.03) \\
.01\end{array}$ & $\begin{array}{l}(.02) \\
-.01\end{array}$ & $\begin{array}{c}(.03) \\
.05\end{array}$ & $\begin{array}{c}(.02) \\
.04\end{array}$ & $\begin{array}{l}(.03) \\
-.02\end{array}$ & $\begin{array}{l}(.02) \\
-.01\end{array}$ \\
\hline Party ID (Republican) & $\begin{array}{l}(.03) \\
-.05\end{array}$ & $\begin{array}{l}(.02) \\
-.03\end{array}$ & $\begin{array}{l}(.03) \\
-.06\end{array}$ & $\begin{array}{l}(.03) \\
-.04\end{array}$ & $\begin{array}{c}(.03) \\
.03\end{array}$ & $\begin{array}{c}(.03) \\
.03\end{array}$ \\
\hline Ideology (Conservative) & $\begin{array}{c}(.02) \\
.04\end{array}$ & $\begin{array}{c}(.02) \\
.02\end{array}$ & $\begin{array}{c}(.02) \\
.03\end{array}$ & $\begin{array}{c}(.02) \\
.02\end{array}$ & $\begin{array}{c}(.02) \\
.02\end{array}$ & $\begin{array}{l}(.02) \\
.02\end{array}$ \\
\hline Authoritarianism & $\begin{array}{c}(.02) \\
.05\end{array}$ & $\begin{array}{l}(.02) \\
-.02\end{array}$ & $\begin{array}{c}(.02) \\
.08\end{array}$ & $\begin{array}{c}(.02) \\
.03\end{array}$ & $\begin{array}{l}(.02) \\
-.02\end{array}$ & $\begin{array}{l}(.02) \\
-.00\end{array}$ \\
\hline & $(.02)$ & $(.02)$ & $(.02)$ & $(.02)$ & $(.02)$ & $(.02)$ \\
\hline Constant & .49 & .08 & .31 & .01 & .72 & .81 \\
\hline & $(.05)$ & $(.04)$ & $(.05)$ & $(.05)$ & $(.05)$ & $(.05)$ \\
\hline $\mathrm{N}$ & 1478 & 1478 & 1478 & 1478 & 1474 & 1474 \\
\hline $\mathrm{R}^{2}$ & .16 & .42 & .10 & .26 & .04 & .06 \\
\hline
\end{tabular}

Note: Entries are unstandardized regression coefficients with standard errors in parentheses. Coefficients in bold are at least two times the size of their standard errors. Variables are coded to range from 0 to 1 except for age (in tens of years) and Education (in years). White is the excluded category for the race/ethnicity dummy variables. 
Table 3

Effects of Security on Trust

\begin{tabular}{|c|c|c|c|c|}
\hline \multirow[b]{2}{*}{ Threat } & \multicolumn{2}{|c|}{$\begin{array}{c}\text { Trust } \\
\text { Americans }\end{array}$} & \multicolumn{2}{|c|}{$\begin{array}{c}\text { Americans } \\
\text { Helpful }\end{array}$} \\
\hline & -.18 & (.19) & .36 & $(.21)$ \\
\hline Security & .47 & $(.14)$ & .50 & $(.16)$ \\
\hline Anxiety & -.35 & $(.17)$ & .09 & $(.20)$ \\
\hline Age & .090 & $(.022)$ & .136 & $(.026)$ \\
\hline Education & .054 & $(.016)$ & .068 & $(.018)$ \\
\hline Gender (female) & -.12 & $(.07)$ & .04 & $(.08)$ \\
\hline Black & -.63 & $(.14)$ & -.31 & $(.14)$ \\
\hline Hispanic & -.30 & $(.15)$ & -.17 & $(.16)$ \\
\hline Other & -.02 & $(.17)$ & -.12 & $(.18)$ \\
\hline Party ID (Republican) & .14 & $(.12)$ & .09 & $(.13)$ \\
\hline Ideology (Conservative) & -.16 & $(.12)$ & -.10 & $(.14)$ \\
\hline Authoritarianism & -.58 & $(.12)$ & -.22 & $(.13)$ \\
\hline Threshold & .46 & $(.32)$ & 1.09 & $(.36)$ \\
\hline \multicolumn{5}{|l|}{ Constant } \\
\hline $\mathrm{N}$ & 1415 & & 1396 & \\
\hline (Pseudo) $\mathrm{R}^{2}$ & .09 & & .06 & \\
\hline
\end{tabular}

Note: Entries are maximum likelihood probit coefficients with standard errors in parentheses. Coefficients in bold are at least twice the size of their standard error. Variables are coded to range from 0 to 1 except for age (in tens of years) and Education (in years). White is the excluded category for the race/ethnicity dummy variables. 
Table 4

\section{Effects of Threat and Security on Anxiety and Depression}

\begin{tabular}{lcccc} 
& \multicolumn{2}{c}{ Anxiety } & \multicolumn{2}{c}{ Depression } \\
Personal Threat &. $\mathbf{8 0}$ & $(.07)$ & $\mathbf{6 6}$ & $(.07)$ \\
Security & .09 & $(.06)$ & .08 & $(.06)$ \\
Threat x Security & -.25 & $(.08)$ & -.29 & $(.09)$ \\
& & & & \\
Age & -.015 & $(.003)$ & .006 & $(.004)$ \\
Education & -.005 & $(.002)$ & -.010 & $(.002)$ \\
Gender (female) & .11 & $(.01)$ & .00 & $(.01)$ \\
$\quad$ Black & -.05 & $(.02)$ & .04 & $(.02)$ \\
Hispanic & -.01 & $(.02)$ & .08 & $(.02)$ \\
$\quad$ Other & -.01 & $(.02)$ & .04 & $(.03)$ \\
Party ID (Republican) & -.02 & $(.02)$ & -.03 & $(.02)$ \\
Ideology (Conservative) & .02 & $(.02)$ & .02 & $(.02)$ \\
Authoritarianism & -.02 & $(.02)$ & .03 & $(.02)$ \\
& & & & \\
Constant & .00 & $(.05)$ & -.04 & $(.06)$ \\
N & 1473 & & 1472 & \\
(Pseudo) R ${ }^{2}$ & .42 & & .27 &
\end{tabular}

Note: Entries are unstandardized regression coefficients with standard errors in parentheses. Coefficients in bold are at least twice the size of their standard error. Variables are coded to range from 0 to 1 except for age (in tens of years) and Education (in years). White is the excluded category for the race/ethnicity dummy variables. 
Table 5

Effects of Threat and Security on Symbolic Patriotism and Negative Arab Stereotypes

\begin{tabular}{|c|c|c|c|c|}
\hline \multirow[b]{2}{*}{ Threat } & \multicolumn{2}{|c|}{$\begin{array}{c}\text { Symbolic } \\
\text { Patriotism }\end{array}$} & \multicolumn{2}{|c|}{$\begin{array}{c}\text { Negative Arab } \\
\text { Stereotypes }\end{array}$} \\
\hline & .41 & $(.07)$ & .25 & $(.09)$ \\
\hline Security & .29 & $(.06)$ & .01 & $(.07)$ \\
\hline Threat x Security & -.32 & $(.09)$ & -.11 & $(.10)$ \\
\hline Anxiety & -.01 & $(.03)$ & -.03 & $(.03)$ \\
\hline Age & .001 & $(.003)$ & .005 & $(.004)$ \\
\hline Education & -.003 & $(.002)$ & -.011 & $(.003)$ \\
\hline Gender (female) & .00 & $(.01)$ & .02 & $(.01)$ \\
\hline Black & -.09 & $(.02)$ & .01 & $(.02)$ \\
\hline Hispanic & -.06 & $(.02)$ & .08 & $(.03)$ \\
\hline Other & -.06 & $(.02)$ & -.03 & $(.03)$ \\
\hline Party ID (Republican) & .04 & $(.02)$ & .03 & $(.02)$ \\
\hline Ideology (Conservative) & .08 & $(.02)$ & .05 & $(.02)$ \\
\hline Authoritarianism & .07 & $(.02)$ & .11 & $(.02)$ \\
\hline Constant & .43 & $(.05)$ & .36 & $(.08)$ \\
\hline $\mathrm{N}$ & 1423 & & 1224 & \\
\hline $\mathrm{R}^{2}$ & .13 & & .13 & \\
\hline
\end{tabular}

Note: Entries are unstandardized regression coefficients with standard errors in parentheses. Coefficients in bold are at least twice the size of their standard error. Variables are coded to range from 0 to 1 except for age (in tens of years) and Education (in years). White is the excluded category for the race/ethnicity dummy variables. 
Table 6

Determinants of Civil Liberty Preferences

\begin{tabular}{|c|c|c|c|c|c|c|}
\hline \multirow[b]{2}{*}{ Threat } & \multicolumn{2}{|c|}{$\begin{array}{c}\text { Support } \\
\text { National ID } \\
\text { Card }\end{array}$} & \multicolumn{2}{|c|}{$\begin{array}{c}\text { Monitor } \\
\text { Phones and } \\
\text { Email }\end{array}$} & \multicolumn{2}{|c|}{$\begin{array}{c}\text { Anti-Terrorism } \\
\text { Laws vs. Civil } \\
\text { Liberties }\end{array}$} \\
\hline & 1.50 & $(.40)$ & .85 & $(.40)$ & 1.82 & $(.54)$ \\
\hline Security & .46 & $(.33)$ & .42 & $(.34)$ & 1.14 & $(.46)$ \\
\hline Threat x Security & -.85 & $(.47)$ & -.25 & $(.47)$ & -1.32 & $(.64)$ \\
\hline Anxiety & .15 & $(.14)$ & .20 & $(.15)$ & -.03 & $(.18)$ \\
\hline Age & .011 & $(.018)$ & .063 & $(.018)$ & .035 & $(.025)$ \\
\hline Education & -.046 & $(.013)$ & -.035 & $(.013)$ & -.000 & $(.017)$ \\
\hline Gender (female) & .04 & $(.06)$ & -.01 & $(.06)$ & .06 & $(.08)$ \\
\hline Black & -.17 & $(.12)$ & -.07 & $(.12)$ & -.20 & $(.15)$ \\
\hline Hispanic & .06 & $(.12)$ & .22 & $(.12)$ & -.23 & $(.16)$ \\
\hline Other & -.02 & $(.14)$ & .13 & $(.14)$ & .06 & $(.17)$ \\
\hline Party ID (Republican) & -.04 & $(.10)$ & .21 & $(.10)$ & .46 & $(.12)$ \\
\hline Ideology (Conservative) & .21 & $(.10)$ & .46 & $(.10)$ & .26 & .13 \\
\hline Authoritarianism & .11 & $(.09)$ & .21 & $(.10)$ & .25 & .12 \\
\hline Threshold 1 & -.11 & $(.35)$ & 1.00 & $(.36)$ & 2.23 & $(.48)$ \\
\hline Threshold 2 & .43 & $(.35)$ & 1.69 & $(.36)$ & & \\
\hline Threshold 3 & 1.24 & $(.35)$ & 2.50 & $(.36)$ & & \\
\hline $\mathrm{N}$ & 1431 & & 1439 & & 1200 & \\
\hline Pseudo $\mathrm{R}^{2}$ & .03 & & .04 & & .05 & \\
\hline
\end{tabular}

Note: Entries are maximum likelihood probit coefficients with standard errors in parentheses. Coefficients in bold are at least twice the size of their standard error. Variables are coded to range from 0 to 1 except for age (in tens of years) and Education (in years). White is the excluded category for the race/ethnicity dummy variables. 
Table 7

Determinants of Preferences on Policies Targeting Arabs

\begin{tabular}{|c|c|c|c|c|c|c|}
\hline \multirow[b]{2}{*}{ Threat } & \multicolumn{2}{|c|}{$\begin{array}{c}\text { Surveillance for } \\
\text { Arabs and Arab } \\
\text { Americans }\end{array}$} & \multicolumn{2}{|c|}{$\begin{array}{c}\text { Toughen } \\
\text { Restrictions on } \\
\text { Visas }\end{array}$} & \multicolumn{2}{|c|}{$\begin{array}{l}\text { Stricter } \\
\text { Security } \\
\text { Checks for } \\
\text { Arabs }\end{array}$} \\
\hline & 1.69 & $(.53)$ & 2.25 & $(.57)$ & 1.29 & $(.45)$ \\
\hline Security & .83 & $(.44)$ & .66 & $(.44)$ & .24 & $(.29)$ \\
\hline Threat x Security & -1.38 & $(.62)$ & -1.47 & $(.68)$ & -.91 & $(.54)$ \\
\hline Anxiety & .09 & $(.18)$ & -.31 & $(.21)$ & .21 & $(.17)$ \\
\hline Age & .059 & $(.024)$ & .157 & $(.028)$ & .064 & $(.022)$ \\
\hline Education & -.021 & $(.016)$ & .019 & $(.019)$ & -.021 & $(.015)$ \\
\hline Gender (female) & -.21 & $(.08)$ & -.08 & $(.09)$ & -.26 & $(.08)$ \\
\hline Black & -.32 & $(.15)$ & -.47 & $(.15)$ & .05 & $(.13)$ \\
\hline Hispanic & -.34 & $(.16)$ & -.41 & $(.16)$ & .13 & $(.15)$ \\
\hline Other & -.44 & $(.21)$ & .00 & $(.20)$ & .05 & $(.16)$ \\
\hline Party ID (Republican) & .24 & $(.12)$ & .19 & $(.14)$ & .00 & $(.11)$ \\
\hline Ideology (Conservative) & .36 & $(.13)$ & .51 & $(.15)$ & .41 & $(.12)$ \\
\hline Authoritarianism & .39 & $(.12)$ & .29 & $(.14)$ & .26 & $(.11)$ \\
\hline Threshold 1 & 2.05 & $(.46)$ & 1.46 & $(.48)$ & 1.00 & $(.40)$ \\
\hline $\mathrm{N}$ & 1334 & & 1419 & & 1429 & \\
\hline Pseudo $\mathrm{R}^{2}$ & .07 & & .11 & & .05 & \\
\hline
\end{tabular}

Note: Entries are maximum likelihood probit coefficients with standard errors in parentheses. Coefficients in bold are at least twice the size of their standard error. Variables are coded to range from 0 to 1 except for age (in tens of years) and Education (in years). White is the excluded category for the race/ethnicity dummy variables. 


\section{Table 8}

\section{Determinants of Support for Military Action}

\begin{tabular}{|c|c|c|c|c|c|c|}
\hline \multirow[b]{2}{*}{ Threat } & \multicolumn{2}{|c|}{$\begin{array}{c}\text { Level of } \\
\text { Military Action }\end{array}$} & \multicolumn{2}{|c|}{$\begin{array}{c}\text { Support } \\
\text { Greater } \\
\text { Military Action }\end{array}$} & \multicolumn{2}{|c|}{$\begin{array}{c}\text { Expand } \\
\text { Military Action } \\
\text { Against } \\
\text { Terrorism }\end{array}$} \\
\hline & 1.70 & $(.44)$ & 1.13 & $(.41)$ & 2.70 & (.59) \\
\hline Security & .56 & $(.36)$ & .68 & $(.34)$ & 1.49 & $(.47)$ \\
\hline Threat x Security & -1.29 & $(.52)$ & -.52 & $(.49)$ & -2.24 & $(.71)$ \\
\hline Anxiety & -.25 & $(.17)$ & -.42 & $(.15)$ & -.55 & $(.21)$ \\
\hline Age & -.040 & $(.021)$ & .021 & $(.020)$ & -.021 & $(.028)$ \\
\hline Education & -.008 & $(.015)$ & -.008 & $(.014)$ & .011 & $(.019)$ \\
\hline Gender (female) & -.25 & $(.07)$ & -.36 & $(.07)$ & -.30 & (.09) \\
\hline Black & -.38 & $(.13)$ & -.50 & $(.12)$ & -.44 & $(.15)$ \\
\hline Hispanic & -.20 & $(.14)$ & -.43 & $(.13)$ & -.40 & $(.17)$ \\
\hline Other & .01 & $(.16)$ & -.26 & $(.14)$ & -.24 & (.19) \\
\hline Party ID (Republican) & .17 & $(.11)$ & .62 & $(.10)$ & .57 & $(.14)$ \\
\hline Ideology (Conservative) & .32 & $(.12)$ & .30 & $(.11)$ & .02 & $(.15)$ \\
\hline Authoritarianism & .30 & $(.11)$ & .24 & $(.11)$ & .27 & $(.14)$ \\
\hline Threshold 1 & -.80 & (.39) & -.04 & $(.36)$ & .75 & $(.51)$ \\
\hline Threshold 2 & 1.65 & (.39) & .52 & $(.36)$ & & \\
\hline Threshold 3 & & & 1.64 & $(.37)$ & & \\
\hline $\mathrm{N}$ & 1381 & & 1309 & & 1369 & \\
\hline Pseudo $\mathrm{R}^{2}$ & .05 & & .07 & & .08 & \\
\hline
\end{tabular}

Note: Entries are maximum likelihood probit coefficients with standard errors in parentheses. Coefficients in bold are at least twice the size of their standard error. Variables are coded to range from 0 to 1 except for age (in tens of years) and Education (in years). White is the excluded category for the race/ethnicity dummy variables. 